\title{
Footfall Drivers in an Indian Apparel Store - National Brand or Private Label
}

\author{
Sushil Raturi \\ Professor-Fashion Management Studies, NIFT Mumbai, India.
}

CITATION: Raturi, Sushil (2019), "Footfall Drivers in an Indian Apparel Store - National Brand or Private Label”, MERC Global's International Journal of Management, Vol. 7, Issue 3, pp. 211-216.

ARTICLE HISTORY: Submitted: January 05, 2019, Revision received: March 06, 2019, Accepted: March 15, 2019

ARTICLE TYPE: Research paper

\begin{abstract}
The presence of multiple National brands in the apparel categories, on one hand, has proved beneficial to the customers in terms of wide choices, on the other hand, has led to immense competition amongst the national brands. The brands are continuously searching for the type of brands which will help them in attracting and retaining customer and ultimately drive business. The purpose of this study is to explore the type of brand which has an impact on customer footfall. The main focus of this quantitative study is to find out real drivers of business for the store. A questionnaire was prepared and a pilot survey was conducted to finalize the questionnaire followed by data collection from one thousand customers. The finding of this study shows that it is a national brand that drives business and there is a significant difference between the footfalls generated by these two forms of brands.
\end{abstract}

KEYWORDS: Footfall, National brand, Private label.

\section{BIBLIOGRAPHY}

1. Abernathy, F.; Dunlop, J.; Hammond, J. and Weil, D. (1999), "A Stitch in Time: Lean Retailing and the transformation of manufacturing: Lessons from the apparel and textile industries", Oxford University Press, Vol. 3, pp. 31-49.

2. Ailawadi, K.; Neslin, S. and Gednek, K. (2001), "Pursuing the value-conscious consumer: Store brand versus national brand promotions", Journal of Marketing, Vol. 65, pp. 71-90.

3. Baidaray, Debjani (2011), "Changing face of Apparel Retail in India", Retail Biz, Vol. 8, Issue 11, pp. 914.

4. Baldinger, A.; Blair, E. and Echambaldi, R. (2002), "Why brands grow", Journal of Advertising Research, Vol. 42, pp. 7-15.

5. Beneke, J. (2010), "Consumer perceptions of private label brands within the retail grocery sector of South Africa", African Journal of Business Management, Vol. 4, Issue 2, pp. 203-220.

6. Bhatnagar, G. (2004), "Retail Revolution", Indian Journal of Marketing, Vol. 34, No. 11, pp. 24-31.

7. Bontems, P.; Monier, S. and Requillart, V. (1999), "Strategic effects of private labels", European Review of Agricultural Economics, Vol. 26, Issue 2, pp. 147-165.

8. Chakraborty, S. (2011), "Perceptions \& Buyer Behaviour Towards Private-Label Colas: An Exploratory Study to Understand the Views of the Store Managers of United Kingdom", The IUP Journal of Marketing Management, Vol. 10, Issue 1, pp. 5-18.

9. Chintagunta, Pradeep K.; Bonfrer, A. and Song, I. (2001), "Investigating the effects of store brand introduction on retailer demand and pricing behaviour", Working paper, Graduate school of Business, University of Chicago.

10. Hoch, S. and Banerji, S. (1993), "When do private labels succeed?", Sloan Management Review, Vol. 34, pp. $57-68$.

11. Jimenez, N. and Martin, S. (2010), "The role of country-of-origin, ethnocentrism and animosity in promoting consumer trust. The moderating role of familiarity", International Business Review, Vol. 19, pp. 34-45. 
12. Jones, T. and Sasser, E. (1995), "Why satisfied Costumers Defect", Harward Busines Review, Vol. 73, Issue 6, pp. 88-99.

13. Kadialy, V., Chintagunta, P. and Naufel, V. (2000), "Manufacturer-retailer interactions and implications for channel power: an empirical investigation of pricing in the local market", Marketing Science, Vol. 19, pp. 127-148.

14. Kapferer, N. (2008), The New Strategic Brand Management: Creating And Sustaining Brand Equity Long Term, London, Kogan.

15. Kardes, R. and Cronley, L. (2004), "The role of selective information processing in price-quality inference", Journal of Consumer Research, Vol. 31, pp. 368-374.

16. Karina, P. (2008), "Apparel Brand endorsers and their effect on purchase intention: A study of Philippine consumers”, Philippine Management Review, Vol. 15, pp. 83-99.

17. Keller, K. L. (1998), Strategic Brand Management, Prentice-Hall, New Jersey.

18. Kumar, Atul (2016), Retailing Strategy of Products \& Customer Services in Organised Retail Sector, PhD Thesis Submitted to Shri Jagdishprasad Jhabarmal Tibrewala University, Vidyanagari, Rajasthan.

19. Kumar, Atul and Brar, Vinaydeep (2016), Retailing Strategy: Products \& Customer Services Perspective, LAP LAMBERT Academic Publishing, Germany, available at: https://www.lappublishing.com/catalog/details//store/gb/book/978-3-330-01953-9/retailing-strategy.

20. Kumar, N. and Steenkamp (2007), "Private label strategy: how to meet the store brand challenge", Harvard Business Press, Boston, Vol. 7, pp. 55-69.

21. Pooja; Mittal, Sanjiv and Kamakshi (2019), "A Study on Impulse Buying Behaviour of Consumers towards Apparels with reference to In-store Environment", MERC Global's International Journal of Management, Vol. 7, Issue 1, pp. 01-08.

22. Vedamani, G. (2006), Retail management- Functional principles \& Practices, Jaico Publishing House, pp. 79-86. 